\title{
Harmaline-resistant mutant of Methanothermobacter thermautotrophicus with a lesion in $\mathrm{Na}^{+} / \mathrm{H}^{+}$antiport
}

\author{
Monika Vidová ${ }^{1}$ Janette Bobálová ${ }^{2}$ and Peter Šmigáň ${ }^{1}$ \\ ${ }^{1}$ Institute of Animal Biochemistry and Genetics, Slovak Academy of Sciences, Ivanka pri Dunaji, Slovak Republic \\ ${ }^{2}$ Institute of Analytical Chemistry of the ASCR, v.v.i., Brno, Czech Republic
}

\begin{abstract}
A spontaneous mutant of Methanothermobacter thermautotrophicus resistant to the $\mathrm{Na}^{+} / \mathrm{H}^{+}$ antiporter inhibitor harmaline was isolated. The $\mathrm{Na}^{+} / \mathrm{H}^{+}$exchange activity in the mutant cells was remarkably decreased in comparison with wild-type cells. $\mathrm{Na}^{+} / \mathrm{H}^{+}$antiport activity of wild-type cells grown in the high $\mathrm{Na}^{+}$concentration $(125 \mathrm{mmol} / \mathrm{l})$ was significantly increased as compared to the cells grown under low $\mathrm{Na}^{+}$concentration $(6.25 \mathrm{mmol} / \mathrm{l})$ conditions. In contrast, harmaline resistant mutant showed almost the same $\mathrm{Na}^{+} / \mathrm{H}^{+}$antiport activity under both these conditions. While harmaline profoundly inhibited methanogenesis in the wild-type, increased methanogenesis was observed both in the presence and absence of harmaline in the mutant strain. ATP synthesis driven by methanogenic electron transport was significantly enhanced in the mutant cells. The experimental data revealed the differential expression of A flavoprotein and molybdenum-containing formylmethanofuran dehydrogenase 1 subunit $\mathrm{C}$ in harmaline-resistant mutant. The overexpression of these proteins might contribute to harmaline resistance. Taken together the results indicate that harmaline resistance in this mutant has arisen as a consequence of mutation(s) in antiporter gene(s) or protein(s) linked to antiporter activity. Moreover this work provides the evidence that $\mathrm{Na}^{+} / \mathrm{H}^{+}$exchanger deficiency in harmaline-resistant mutant can induce overexpression of several proteins participating in methanogenesis.
\end{abstract}

Key words: Methanogens - Harmaline resistance - Sodium/proton exchange

\section{Introduction}

Methanogens as members of the Archaea, belong to a group of microorganisms containing both $\mathrm{H}^{+}$- and $\mathrm{Na}^{+}$-dependent energetic cycle and the $\mathrm{Na}^{+} / \mathrm{H}^{+}$antiporter(s). Despite numerous studies, the physiological and bioenergetic roles of these two bioenergetic cycles and of the $\mathrm{Na}^{+} / \mathrm{H}^{+}$antiporter have not been satisfactorily explained so far. Kaesler and Schönheit (1989) have suggested that primarily generated electrochemical sodium gradient $\left(\Delta \tilde{\mu}_{\mathrm{Na}+}\right)$ can be converted in Methanothermobacter thermautotrophicus by means of $\mathrm{Na}^{+} / \mathrm{H}^{+}$antiporter activity to electrochemical proton gradient $\left(\Delta \tilde{\mu}_{\mathrm{H}_{+}}\right)$. The resulting $\Delta \tilde{\mu}_{\mathrm{H}_{+}}$can be utilized via the $\mathrm{A}_{1} \mathrm{~A}_{0}$ ATP synthase for ATP production (Kaesler and Schönheit

Correspondence to: Peter Šmigáň, Institute of Animal Biochemistry and Genetics, Slovak Academy of Sciences, Moyzesova 61, 90028 Ivanka pri Dunaji, Slovak Republic

E-mail: peter.smigan@savba.sk
1989; Schäfer et al. 1999). In methanogens containing cytochromes, the $\mathrm{H}_{2}$ :heterodisulfide oxidoreductase system and $\mathrm{F}_{420} \mathrm{H}_{2}$ :heterodisulfide oxidoreductase system are associated with membrane and coupled to proton translocation (Deppenmeier and Müller 2008). On the contrary it was suggested that in methanogens without cytochromes, the corresponding $\mathrm{H}_{2}$ :heterodisulfide reductase is only loosely associated with cytoplasmic membrane and is probably not coupled to proton translocation (Thauer et al. 2008). In such a case $\mathrm{Na}^{+} / \mathrm{H}^{+}$ antiporter might be an exclusive $\Delta \tilde{\mu}_{\mathrm{H}+}$ generator. These ideas present an unusual new energetic situation in methanogens and $\mathrm{Na}^{+} / \mathrm{H}^{+}$antiporter might acts in this complex energetic system as a basic regulatory element especially in cell without cytochromes, such as $M$. thermoautotrophicus. Inhibitory studies of $\mathrm{Na}^{+} / \mathrm{H}^{+}$exchanger in methanoarchaea suggested that it is involved in $\mathrm{pH}$ and $\mathrm{pNa}$ homeostasis but its function in bioenergetics of methanoarchaea has not been resolved yet.

The understanding of the function of $\mathrm{Na}^{+} / \mathrm{H}^{+}$exchanger and its cooperation with above mentioned bioenergetic sub- 
systems requires new experimental tools. We suggested that genetic approach to modulation or elimination of $\mathrm{Na}^{+} / \mathrm{H}^{+}$ antiport in cells of $M$. thermoautotrophicus might be suitable for these purposes. Recently we have isolated a spontaneous mutant of $M$. thermautotrophicus resistant to the $\mathrm{Na}^{+} / \mathrm{H}^{+}$ antiporter inhibitor amiloride (Šurín et al. 2007). The study of the $\mathrm{Na}^{+} / \mathrm{H}^{+}$antiporter in the amiloride-resistant mutant has shown that this mutant exhibits very specific phenotypic characteristics like reduced $\mathrm{Na}^{+} / \mathrm{H}^{+}$antiport and elevated production of methane and ATP. The molecular study of amiloride-resistant mutant did not allow us to assign a $\mathrm{Na}^{+} /$ $\mathrm{H}^{+}$antiporter activity to a product of a particular gene from the $M$. thermautotrophicus genome or to identify protein(s) participating in this complex process. Therefore we decided to isolate mutants resistant to harmaline as another inhibitor of $\mathrm{Na}^{+} / \mathrm{H}^{+}$antiporter in methanoarchaea (Schönheit and Beimborn 1985; Šmigáň et al. 1995). Such a mutant could have alterations in $\mathrm{Na}^{+} / \mathrm{H}^{+}$antiporter itself and could thus provide a tool to extend our knowledge on the properties and the physiological role of $\mathrm{Na}^{+} / \mathrm{H}^{+}$antiporter and its bioenergetic function in $M$. thermautotrophicus. Moreover, the molecular study of such mutant could provide a very promising experimental approach for identification of the protein/gene for the $\mathrm{Na}^{+} / \mathrm{H}^{+}$antiporter and could lead to new ideas on the molecular mechanism of energy coupling in methanoarchaea. This paper reports on a mutant of $M$. thermautotrophicus resistant to harmaline exhibiting a lesion in $\mathrm{Na}^{+} / \mathrm{H}^{+}$antiporter activity accompanied by an increase in methane and ATP formation. Moreover, this study revealed the differential expression of several proteins that may contribute to harmaline resistance in the mutant strain.

\section{Materials and Methods}

Growth conditions and isolation of harmaline-resistant mutant

Growth conditions of the M. thermautotrophicus strain $\Delta H$ were as described earlier (Šmigán et al. 1984). Solid media were prepared by the addition of $1 \%(\mathrm{w} / \mathrm{v})$ Gelrite to the medium. All manipulations were performed under strict anaerobic conditions. For the isolation of harmaline-resistant mutant of $M$. thermautotrophicus, growth medium (Šmigán et al. 1984) containing $\mathrm{K}_{2} \mathrm{CO}_{3}$ instead of $\mathrm{Na}_{2} \mathrm{CO}_{3}$ was supplemented with $6.25 \mathrm{mmol} / \mathrm{l} \mathrm{NaCl}$. To select harmaline-resistant mutants, cultures were grown for $24 \mathrm{~h}$ in liquid medium in the presence of $800 \mu \mathrm{mol} / 1$ harmaline. Cells were washed in growth medium and $1 \times 10^{8}$ cells were plated directly in an anaerobic box (Forma Scientific, model 1024) on solid medium ( $\mathrm{pH} 7$ ) containing harmaline. Plates were incubated at $60^{\circ} \mathrm{C}$ in a stainless-steel anaerobic jar for 14 days. Eight clones able to grow in the presence of harmaline were isolated and one of them was characterised in this study.

\section{Measurements of $\mathrm{Na}^{+} / \mathrm{H}^{+}$antiport activity}

$\mathrm{Na}^{+}$-induced $\mathrm{pH}$ changes in weakly buffered cell suspensions were monitored by Orion 91-03 semimicroelectrode connected to Orion Research Ion Analyser 901 equipped with Kipp-Zonen BD40 recorder.

Spectrofluorimetric measurements of $\mathrm{Na}^{+} / \mathrm{H}^{+}$antiport activity were performed as described earlier (Šmigáň et al. 1995) with following modifications. Exponentially grown cells were harvested and washed in $20 \mathrm{mmol} / \mathrm{l}$ MES buffer containing $50 \mathrm{mmol} / 1 \mathrm{NH}_{4} \mathrm{Cl}\left(\mathrm{pH}\right.$ 6), under $\mathrm{N}_{2}$ atmosphere, resuspended in $20 \mathrm{mmol} / \mathrm{l} \mathrm{HEPES}, 10 \mathrm{mmol} / \mathrm{l} \mathrm{KCl} \mathrm{(pH} \mathrm{7),}$ to final concentration of $4.5 \mathrm{mg}$ of cell proteins per milliliter, and maintained at $7^{\circ} \mathrm{C}$ under $\mathrm{N}_{2}$ atmosphere. Aliquots of cells corresponding to $45 \mu \mathrm{g}$ of cell protein were transferred to a stirred anaerobic cuvette containing $2 \mathrm{ml}$ of buffer: 50 $\mathrm{mmol} / \mathrm{l} \mathrm{HEPES}, 10 \mathrm{mmol} / \mathrm{KCl}, 5 \mathrm{mmol} / \mathrm{l} \mathrm{MgCl}_{2}$ and 2.5 $\mathrm{mmol} / \mathrm{l}$ acridine orange preheated to $55^{\circ} \mathrm{C}$. Quenching and $\mathrm{Na}^{+}$-induced dequenching of acridine orange were monitored under $\mathrm{N}_{2}$ atmosphere at $55^{\circ} \mathrm{C}$ using PerkinElmer LS-50B spectrofluorimeter at excitation and emission wavelengths of 493 and $530 \mathrm{~nm}$, respectively. Fluorescence before cells addition was assumed to be $100 \%$.

\section{Subcellular fractionation, analysis and identification of proteins}

Soluble supernatant fractions (centrifuged at $100000 \times g$ ) and membrane vesicle proteins were isolated as described previously (Majerník et al. 2003). Membrane vesicles were also used to prepare chloroform/methanol extracts according to (Ruppert et al. 2001). Soluble supernatant fractions and membrane vesicles were analysed by a native polyacrylamide gel electrophoresis (PAGE) (Laemmli 1970) without the addition of sodium dodecyl sulfate (SDS) and 2-mercaptoethanol to buffers. SDS-PAGE was performed according to (Schägger and von Jagow 1987). Protein bands stained by Coomassie blue staining were excised from the gel, digested by trypsin and analysed using a MALDI TOF/ TOF 4700 Proteomic Analyser (ABI). The Mascot search engine was used to identify cognate proteins by matching MS of detected peptides to $M$. thermautotrophicus proteins. Proteins were quantified by the Lowry method (Lowry et al. 1951) using bovine serum albumin (BSA) as standard.

\section{Measurement of methane and ATP formation}

Methane formation from $\mathrm{CO}_{2}$ and $\mathrm{H}_{2}$ by the cell suspension was measured by an analysis of glass vial headspace gases by GC. Aliquots were measured using a CarloErba Fractovap 4200 equipped with a 2-m steel column packed with Sepharon AE $200-300 \mu \mathrm{m}$ and a thermal conductivity detector using argon as a carrier gas (Šmigán et al. 1984). ATP synthesis 


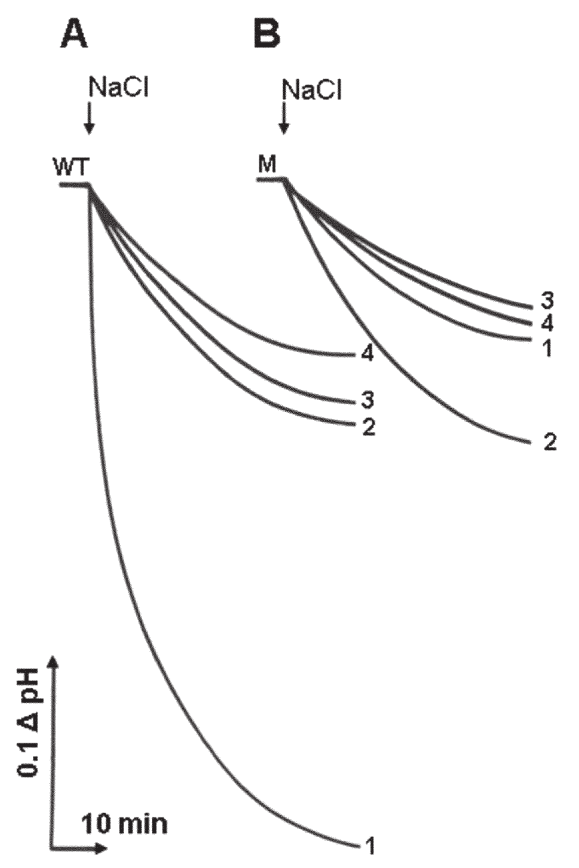

Figure 1. Changes of external $\mathrm{pH}$ in suspensions of $M$. thermautotrophicus wild-type (WT) cells (A) and harmaline resistant mutant (M) cells (B). Cells grown to exponential phase either in the presence of $125 \mathrm{mmol} / \mathrm{l} \mathrm{NaCl}\left(\right.$ high $\mathrm{Na}^{+}$) or $6.5 \mathrm{mmol} / \mathrm{l} \mathrm{NaCl}\left(\right.$ low $\mathrm{Na}^{+}$) were harvested, washed and resuspended in buffer $(0.2 \mathrm{~mol} / \mathrm{l} \mathrm{KCl}, 2 \mathrm{mmol} /$ 1 Tris : $\mathrm{HCl}, \mathrm{pH} 6.8)$ to a concentration of $1.1 \mathrm{mg}$ protein $/ \mathrm{ml}$, transferred to a double-necked vial and incubated at $60^{\circ} \mathrm{C}$ under constant stirring. A. High $\mathrm{Na}^{+}$cells: control (1), $800 \mu \mathrm{mol} / \mathrm{l}$ harmaline (2). Low $\mathrm{Na}^{+}$cells: control (3), $800 \mu \mathrm{mol} / \mathrm{l}$ harmaline (4). B. High $\mathrm{Na}^{+}$cells: control (1), $800 \mu \mathrm{mol} / \mathrm{l}$ harmaline (2). Low $\mathrm{Na}^{+}$cells: control (3), 800 $\mu \mathrm{mol} / \mathrm{l}$ harmaline (4). Cells grown in the presence of $6.5 \mathrm{mmol} / \mathrm{l} \mathrm{NaCl}$. The arrows indicate the addition of $\mathrm{NaCl}$ to a final concentration of $60 \mathrm{mmol} / \mathrm{l}$. All experiments were reproducibly repeated at least three times, and a representative data set is shown.

driven by methanogenic electron transport in cell suspensions of the wild-type and harmalin-resistant mutant was measured according to Schönheit and Perski (1983).

\section{Results}

Harmaline and amiloride have been shown to be competetive inhibitors of the $\mathrm{Na}^{+} / \mathrm{H}^{+}$antiporter in $M$. thermautotrophicus (Schönheit and Beimborn 1985). It is important to emphasize that these two substances are chemically unrelated. Recently we have isolated a spontaneous mutant of $M$. thermautotrophicus resistant to the $\mathrm{Na}^{+} / \mathrm{H}^{+}$antiporter inhibitor amiloride (Šurín et al. 2007).

To extend our knowledge on the function of this antiporter we tried to isolate a new spontaneous mutant of M. thermautotrophicus resistant to $800 \mu \mathrm{mol} / \mathrm{l}$ harmaline.
Wild-type and the harmaline-resistant mutant strains showed comparable growth yields $(0.245 \mathrm{mg}$ and $0.24 \mathrm{mg}$ of total cell protein $/ \mathrm{ml}$ of growth medium, respectively) after $24 \mathrm{~h}$ of growth in standard culture media with 125 $\mathrm{mmol} / \mathrm{l} \mathrm{NaCl}$. We hypothetized that harmaline-resistant mutant might have alterations in $\mathrm{Na}^{+} / \mathrm{H}^{+}$antiporter itself as it was found in amiloride resistant mutant. To test the $\mathrm{Na}^{+} / \mathrm{H}^{+}$antiporter activity of harmaline-resistant mutant and wild-type cells, the extent of $\mathrm{Na}^{+}$-induced acidification of the external medium by cell suspension cultivated in liquid media supplemented with $6.25 \mathrm{mmol} / \mathrm{l}$ or $125 \mathrm{mmol} / \mathrm{l} \mathrm{NaCl}$ was monitored. The $\mathrm{Na}^{+} / \mathrm{H}^{+}$exchanger activity in the mutant cells was remarkably decreased in comparison with wildtype cells. The $\mathrm{Na}^{+} / \mathrm{H}^{+}$antiport activity of wild-type cells grown in the high sodium ion concentration $(125 \mathrm{mmol} / \mathrm{l})$ was significantly increased as compared to the cells grown under low $\mathrm{Na}^{+}(6.25 \mathrm{mmol} / \mathrm{l})$ conditions. On the other hand, the harmaline-resistant mutant showed almost the same $\mathrm{Na}^{+} / \mathrm{H}^{+}$antiport activity under both conditions (Figure 1). Harmaline profoundly inhibited the $\mathrm{Na}^{+} / \mathrm{H}^{+}$antiporter activity in the wild-type while this inhibitor even stimulated $\mathrm{Na}^{+} / \mathrm{H}^{+}$exchange in mutant cells (Figure 1 ). The results of these experiments demonstrate that the increasing $\mathrm{Na}^{+}$ ion concentration in growth medium leads to a significant increase of the $\mathrm{Na}^{+} / \mathrm{H}^{+}$antiporter activity in wild-type cells. These results also indicate that $\mathrm{Na}^{+} / \mathrm{H}^{+}$antiporter is inductive in $M$. thermautotrophicus.

To characterize $\mathrm{Na}^{+} / \mathrm{H}^{+}$antiporter activity in the harmaline-resistant mutant strain in more detail, a spectrofluorimetric method was used for determination of kinetic parameters for the $\mathrm{Na}^{+} / \mathrm{H}^{+}$exchange in both wild-type and mutant cells, respectively. The apparent maximum velocity $\mathrm{V}_{\max }$ and Michaelis constant $\mathrm{K}_{\mathrm{M}}$ were 73.6 a.u. (arbitrary unit) and $5.5 \mathrm{mmol} / \mathrm{l}$ for the wild-type, and 47.6 a.u. and $4.4 \mathrm{mmol} / \mathrm{l}$ for the mutant. Almost two-fold decrease in $\mathrm{V}_{\text {max }}$ in the mutant strain indicates either a reduced amount of $\mathrm{Na}^{+} / \mathrm{H}^{+}$antiporter or a lower catalytic efficiency rather than a change in its affinity for $\mathrm{Na}^{+}$ions. These results were similar to our results obtained in the study of amiloride resistant mutant.

In 1985, Schönheit and Beimborn presented the evidence for a function of the $\mathrm{Na}^{+} / \mathrm{H}^{+}$antiporter in methane formation and intracellular $\mathrm{pH}$ regulation (Schonheit and Beimborn 1985). It was therefore interesting to study the effect of significantly reduced activity of the $\mathrm{Na}^{+} / \mathrm{H}^{+}$antiporter in harmaline-resistant mutant on $\mathrm{Na}^{+}$-dependent methane formation. As can be seen in Figure 2, harmaline-resistant mutant exhibited methanogenesis under resting conditions even in the presence of $800 \mu \mathrm{mol} / \mathrm{l}$ harmaline, whereas methanogenesis was strongly inhibited under the same conditions in the wild-type cells. Since $\mathrm{Na}^{+} / \mathrm{H}^{+}$antiporter activity is supposed to be sensitive to uncoupling, we tested the effect of the uncoupler 3,30,40,5-tetrachlorosalicylanilide 

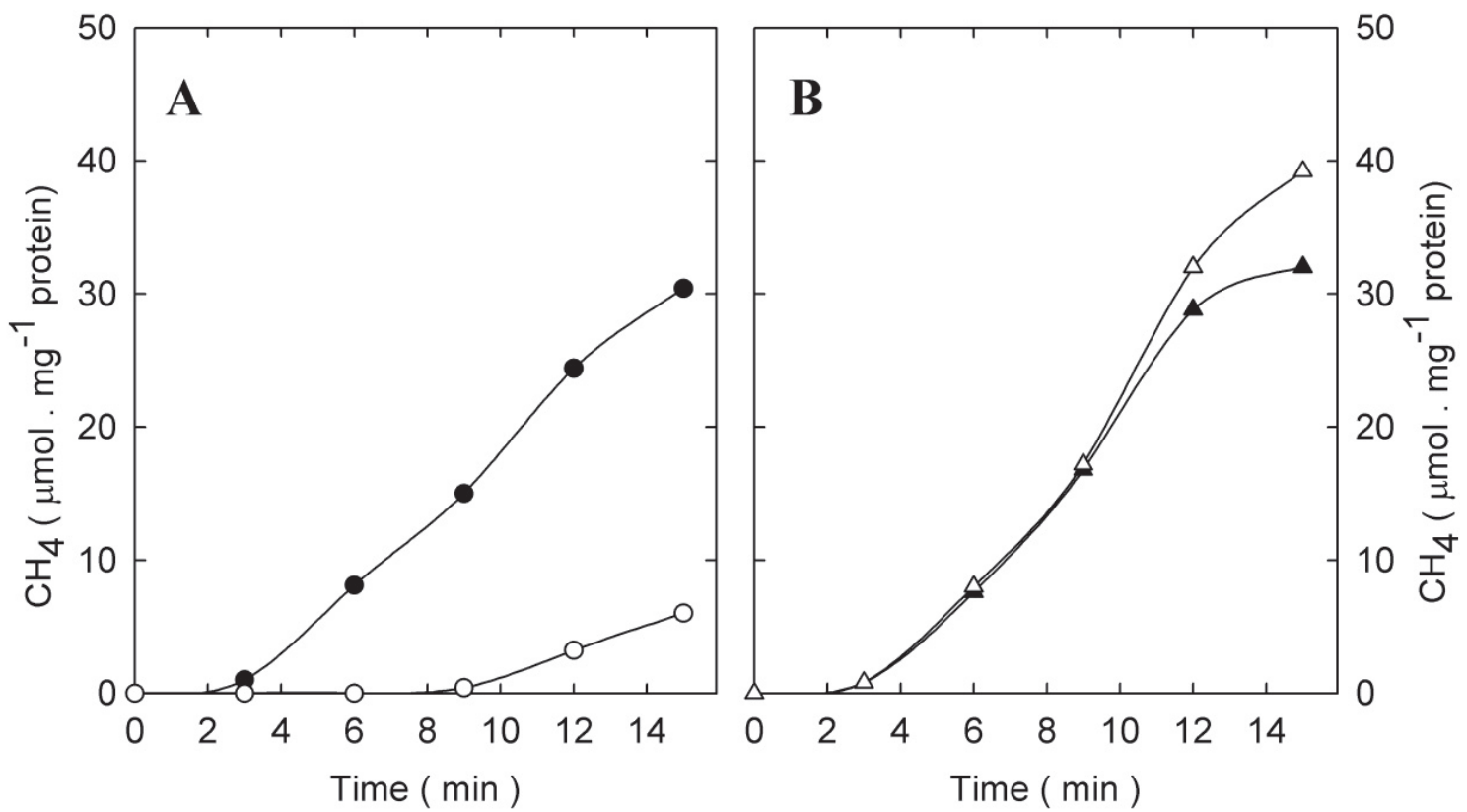

Figure 2. Time course of methane formation from $\mathrm{H}_{2} / \mathrm{CO}_{2}$ in the wild-type and harmaline-resistant mutant of M. thermautotrophicus. Cells were suspended in $50 \mathrm{mmol} / \mathrm{l}$ MOPS-Tris buffer ( $\mathrm{pH} 6.8$ ), $10 \mathrm{mmol} / \mathrm{l} \mathrm{NaCl}$ and $5 \mathrm{mmol} / \mathrm{l} \mathrm{MgCl} 2$ to a concentration of $1.8 \mathrm{mg}$ protein $/ \mathrm{ml}$. The suspensions in $22 \mathrm{ml}$ flasks were pressurized with $\mathrm{H}_{2} / \mathrm{CO}_{2}(4: 1)$ to $100 \mathrm{kPa}$ and incubated at $60^{\circ} \mathrm{C}$. A. Wild-type cells: control $(\bullet), 800 \mu \mathrm{mol} / \mathrm{l}$ harmaline $(\mathrm{O}) \mathbf{B}$. Mutant cells: control $(\boldsymbol{\Delta}), 800 \mu \mathrm{mol} / \mathrm{l}$ harmaline $(\Delta)$. Methane was measured at the times indicated. All experiments were reproducibly repeated at least three times and a representative data set is shown.

(TCS) on growth and methane production in the wild-type and harmaline-resistant mutant cells. Significant differences were found between the ability of mutant and wild-type cells to synthesize methane and to grow in the presence of this uncoupler (Table 1).

While harmaline and TCS strongly inhibited growth and methanogenesis in the wild-type, both parameters were insensitive to these inhibitors in the mutant strain. These findings support the idea that in wild-type cells, $\Delta \tilde{\mu}_{\mathrm{Na}+}$ can be converted to $\Delta \tilde{\mu}_{\mathrm{H}+}$ by $\mathrm{Na}^{+} / \mathrm{H}^{+}$antiporter (Kaesler and Schönheit 1989) and resulting $\Delta \tilde{\mu}_{\mathrm{H}+}$ can be then directly utilized via the $\mathrm{A}_{1} \mathrm{~A}_{0} \mathrm{ATP}$ synthase for ATP production. In the mutant strain with modified $\mathrm{Na}^{+} / \mathrm{H}^{+}$antiport system, $\Delta \tilde{\mu}_{\mathrm{Na}+}$ cannot be converted by means of the $\mathrm{Na}^{+} / \mathrm{H}^{+}$antiporter to $\Delta \tilde{\mu}_{\mathrm{H}+}$. Moreover, $\Delta \tilde{\mu}_{\mathrm{H}+}$ cannot be generated in these cells by $\Delta \tilde{\mu}_{\mathrm{H}}$ generator $-\mathrm{H}_{2}$ : heterodisulphid reductase since this enzyme does not work in the methanoarchaea cells lacking cytochromes (Deppenmeier et al. 1996; Thauer et al. 2008). This indicates that $\mathrm{Na}^{+}$ ions are the exclusive coupling ions in this mutant. Amiloride $(800 \mu \mathrm{mol} / \mathrm{l})$, another inhibitor of the $\mathrm{Na}^{+} / \mathrm{H}^{+}$antiporter in methanoarchaea, inhibited methane formation in the harmaline-resistant mutant strain under non-growing conditions (not shown). This demonstrated the absence of crossresistance between harmaline and amiloride in the harmaline-resistant mutant and indicated different biochemical mechanisms of re- sistance to harmaline and amiloride in $M$. thermautotrophicus. $\mathrm{Na}^{+} / \mathrm{H}^{+}$antiport in methanoarchaea seems to be a process that couples the circulation of $\mathrm{H}^{+}$and $\mathrm{Na}^{+}$ions across the cytoplasmic membrane.

As mentioned earlier, $\mathrm{Na}^{+} / \mathrm{H}^{+}$antiporter could modulate the driving force for ATP synthesis under physiological conditions (Kaesler and Schönheit 1989; Šmigáň et al. 1995). Therefore, we studied the potential role of the $\mathrm{Na}^{+} / \mathrm{H}^{+}$antiporter in total ATP synthesis in more detail. Comparison of wild-type and mutant ATP synthesis driven by methanogenic electron transport has shown that total ATP synthesis is

Table 1. Effect of TCS and harmaline on methane production of wild-type and harmaline-resistant mutant ${ }^{a}$

\begin{tabular}{lcc}
\hline \multirow{2}{*}{ Treatment } & \multicolumn{2}{c}{$\mathrm{CH}_{4} / 24 \mathrm{~h}(\mathrm{mmol})$} \\
\cline { 2 - 3 } & Wild-type & Mutant \\
\hline Control & 1.3 & 1.2 \\
TCS & 0.26 & 1.2 \\
Harmaline & 0.0 & 1.16 \\
\hline
\end{tabular}

$\bar{a}$ Wild-type and harmaline-resistant mutant were cultivated in medium supplemented with $125 \mathrm{mmol} / \mathrm{l} \mathrm{NaCl}$ in the presence of $3 \mu \mathrm{mol} / \mathrm{l} \mathrm{TCS}$ or $800 \mu \mathrm{mol} / \mathrm{l}$ harmaline. Methane was determined after $24 \mathrm{~h}$ by gas chromatography. 
higher in the mutant strain (Figure 3). We have also determined the effect of significantly reduced $\mathrm{Na}^{+} / \mathrm{H}^{+}$antiporter activity in the mutant strain on ATP synthesis driven by an electrogenic potassium efflux in the presence of sodium ions. The results clearly showed significantly enhanced ATP synthesis in the harmaline-resistant mutant (Figure 4). It should be noted in this context that native PAGE combined with MALDI TOF/TOF mass spectrometry did not reveal increased levels of $A_{1}$ and $A_{0}$ subcomplexes of the $A_{1} A_{0}$-type synthase in the mutant strain (not shown).

These findings indicate that the $\mathrm{Na}^{+} / \mathrm{H}^{+}$antiporter may compete with the $\mathrm{Na}^{+}$-translocating ATP synthase for sodium ions during ATP synthesis, as it was suggested previously (Šmigán et al. 1995). Similarly, Becher and Müller (1994) have found that inhibition of the $\mathrm{Na}^{+} / \mathrm{H}^{+}$antiporter in M. mazei led to a stimulation of ATP synthesis driven by a methyl transfer reaction generating $\Delta \mu_{\mathrm{Na}}^{+}$, as well as by artificially created $\Delta \mathrm{pNa}$.

To identify molecular basis of the harmaline resistance, mass spectrometry analysis of the protein composition of membrane vesicles and supernatant fraction derived from wild-type and

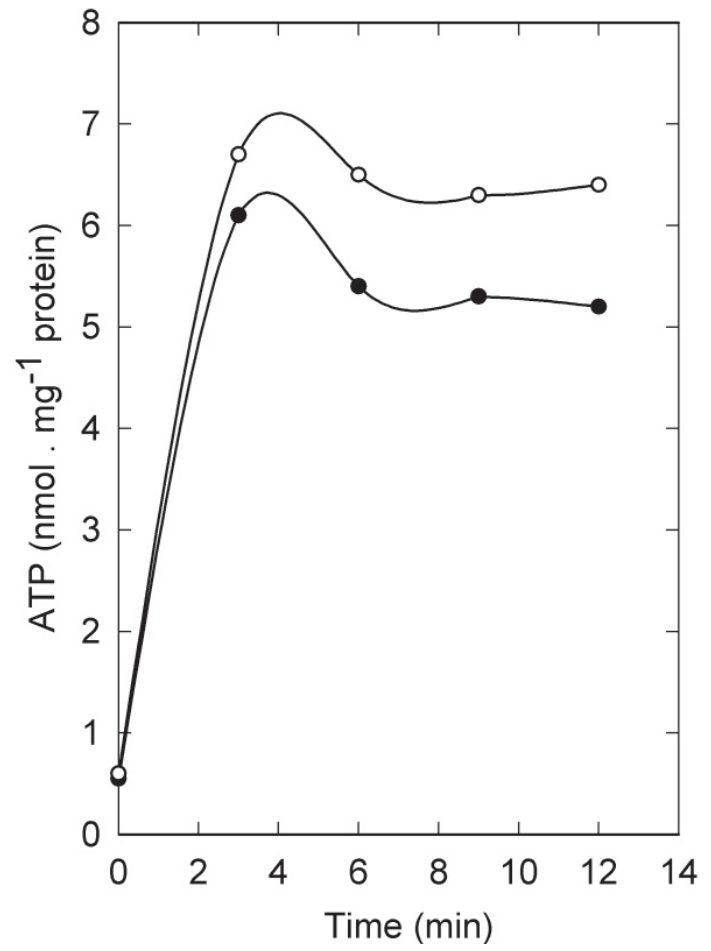

Figure 3. Methanogenesis-driven ATP synthesis in the wild-type and harmaline-resistant mutant of $M$. thermautotrophicus. Cells were suspended in $50 \mathrm{mmol} / \mathrm{l} \mathrm{MOPS}$-Tris buffer (pH 6.8), $10 \mathrm{mmol} / \mathrm{l}$ $\mathrm{NaCl}$ and $5 \mathrm{mmol} / \mathrm{l} \mathrm{MgCl}_{2}$ to a concentration of $1.1 \mathrm{mg}$ protein $/ \mathrm{ml}$. Gas phase was $80 \% \mathrm{H}_{2} / 20 \% \mathrm{CO}_{2}$. wild-type cells, $\mathrm{O}$ mutant cells. All experiments were reproducibly repeated at least three times and a representative data set is shown. harmaline-resistant cells was performed. The preliminary results of MS analysis of the protein composition of membrane vesicles and supernatant fractions revealed that mutant cells contained significantly higher amounts of type A flavoprotein and molybdenum-containing formylmethanofuran dehydrogenase. It has been suggested recently that these proteins play a direct role in flavin-based electron bifurcation in methanoarchaea lacking cytochromes (Thauer et al. 2008).

\section{Discussion}

The coexistence of two primary ion gradients $\Delta \tilde{\mu}_{\mathrm{H}+}$ and $\Delta \tilde{\mu}_{\mathrm{Na}}$ in methanoarchaea representing a completely unprecedented energetic situation in prokaryotic cells could have lead to the evolution of specific transport system(s). This system might be a basic regulatory element responsible for the homeostasis of $\mathrm{Na}^{+}$- and $\mathrm{H}^{+}$-cycles in methanoarchaea. We suggested $\mathrm{Na}^{+} / \mathrm{H}^{+}$antiporter as one of candidates for this role. To test this hypothesis, we applied genetic approach to prepare a model system in which modulation and/or elimination of this antiporter would be viable.

Three years ago we isolated a spontaneous $M$. thermautotrophicus mutant resistant to the $\mathrm{Na}^{+} / \mathrm{H}^{+}$antiporter inhibitor amiloride (Šurín et al. 2007). Biochemical and proteomic study of this mutant did not definitely clarify neither the predicted function of this antiporter in balancing the energy of $\Delta \tilde{\mu}_{\mathrm{H}+}$ and $\Delta \tilde{\mu}_{\mathrm{Na}+}$ nor the protein components responsible for $\mathrm{Na}^{+} / \mathrm{H}^{+}$exchange in the bioenergetics of M. thermautotrophicus. As an extension of these studies we isolated harmaline-resistant mutant of $M$ thermautotrophicus. The finding that growth in the presence of high sodium concentration is associated with an elevated $\mathrm{Na}^{+} / \mathrm{H}^{+}$ antiporter activity in wild-type cells suports the idea that the expression of this exchanger is regulated by sodium ions. It also indicates that sodium dependence of methanoarchaea is mediated not only by $\mathrm{N}-5$-methyltetrahydromethanopterin: coenzyme M methyltransferase (EC 2.1.1.86) as generator of $\Delta \tilde{\mu}_{\mathrm{Na}+}$ (a primary sodium pump) (Becher et al. 1992) but also by the $\mathrm{Na}^{+} / \mathrm{H}^{+}$exchanger. Recently we observed a significant increase in $\mathrm{Na}^{+} / \mathrm{H}^{+}$antiporter activity when cells progressed into the stationary growth phase. We can assume that $M$. thermautotrophicus has either one $\mathrm{Na}^{+} / \mathrm{H}^{+}$ antiporter differently regulated by $\mathrm{Na}^{+}$concentration or that there are at least two independent $\mathrm{Na}^{+} / \mathrm{H}^{+}$antiporter systems each controlled by different mechanisms. Results obtained from kinetic measurements indicate that $\mathrm{Na}^{+} / \mathrm{H}^{+}$ antiporter in the mutant strain is either present in reduced amounts or it exhibits lower catalytic efficiency rather than it would have modified affinity for $\mathrm{Na}^{+}$ions. Similar results were achieved also in the study of amiloride resistant mutant. As mentioned above, $M$. thermautotrophicus belongs to a group of methanoarchaea without cytochromes, and its 
$\mathrm{H}_{2}$ :heterodisulphid reductase is a cytoplasmic enzyme and is not coupled to transmembrane proton translocation. If this assumption is valid, $\mathrm{Na}^{+} / \mathrm{H}^{+}$antiporter is the only possible generator of $\Delta \tilde{\mu}_{\mathrm{H}+}$.

The results described above have raised the question if harmaline-resistant mutant cells can grow when $\Delta \tilde{\mu}_{\mathrm{H}+}$ is dissipated in the presence of protonophore TCS. To answer this question, we studied the inhibitory effect of TCS on the methane formation in growing wild-type and harmaline-resistant mutant cells (Table 1). Our results indicate that $\Delta \tilde{\mu}_{\mathrm{H}+}$ is a driving force for at least some endergonic processes in the wilde-type cells grown in the presence of high $\mathrm{NaCl}(125.0 \mathrm{mmol} / \mathrm{l} \mathrm{NaCl})$ and that $\mathrm{Na}^{+} / \mathrm{H}^{+}$exchange activity sensitive to harmaline is responsible for generation of $\Delta \tilde{\mu}_{\mathrm{H}+}$. On the other hand, mutant cells can grow under the same conditions in the presence of protonophore TCS and harmaline. This supports the idea that harmaline-resistant mutant with modified $\mathrm{Na}^{+} / \mathrm{H}^{+}$antiporter can grow in the absence of $\Delta \tilde{\mu}_{\mathrm{H}+}$ that should be dissipated in the presence of uncoupler. This finding also indicates that only

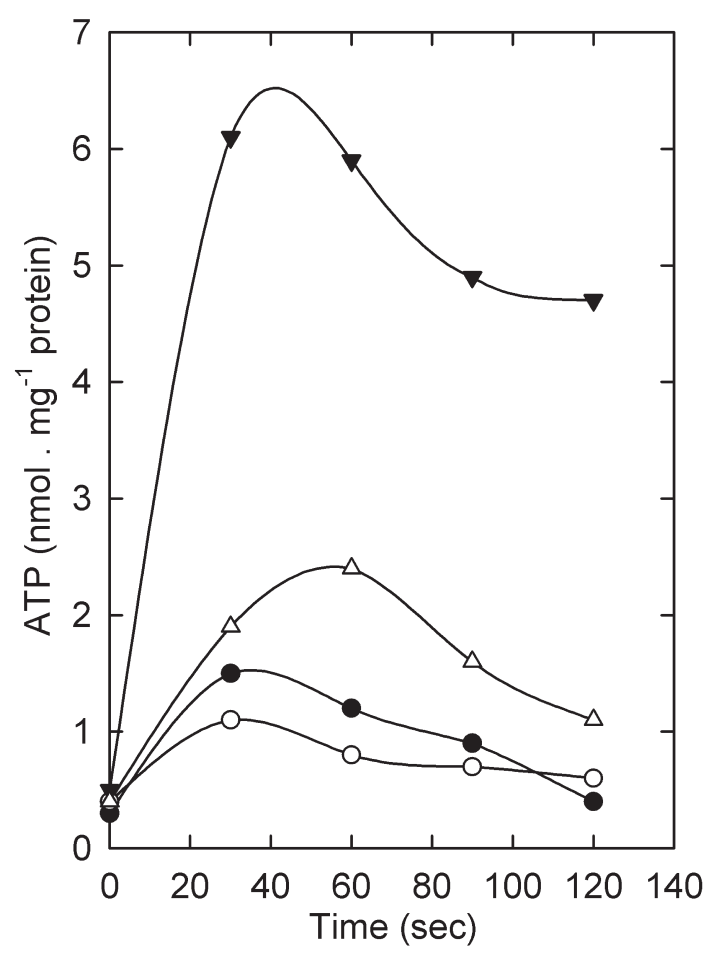

Figure 4. Potassium diffusion potential-driven ATP synthesis in the wild-type and harmaline-resistant mutant of $M$. thermautotrophicus. Cells were suspended in $50 \mathrm{mmol} / \mathrm{l}$ MOPS-Tris buffer ( $\mathrm{pH}$ 6.8) to a concentration of $3.0 \mathrm{mg}$ protein/ml. After $5 \mathrm{~min}$ of preincubation at $60^{\circ} \mathrm{C}$, ATP synthesis was induced by the addition of valinomycin (f.c. $15 \mu \mathrm{mol} / \mathrm{l}$ ). At $\mathrm{t}=5 \mathrm{~min}, \mathrm{NaCl}$ was added to f.c. $50 \mathrm{mmol} / \mathrm{l}$. Wild-type cells: control $(\bullet), 3 \mu \mathrm{mol} / \mathrm{l} \mathrm{TCS}(\mathrm{O})$. Mutant cells: control $(\boldsymbol{\Delta}), 3 \mu \mathrm{mol} / \mathrm{l} \operatorname{TCS}(\Delta)$.
$\Delta \tilde{\mu}_{\mathrm{Na}}$ generated by N-5-methyltetrahydromethanopterin: coenzyme M methyltransferase (EC 2.1.1.86) drives ATP synthesis and that $\mathrm{Na}^{+}$ion is the exclusive coupling ion in this mutant. This means also that $\Delta \tilde{\mu}_{\mathrm{H}+}$ generator $\mathrm{H}_{2}$ : heterodisulphid reductase, generating $\Delta \tilde{\mu}_{\mathrm{H}+}$ by redox potential-driven proton translocation (Deppenmeier et al. 1996), does not work in cells lacking cytochromes as suggested by Thauer et al. (2008). These authors suggested recently that in methanoarchaea group with cytochromes the first and last steps in methanogenesis from $\mathrm{H}_{2}$ and $\mathrm{CO}_{2}$ are coupled chemiosmotically (Thauer et al. 2008). M. thermautotrophicus belong to a group lacking cytochromes. Gunsalus and Wolfe (1977) observed in M. thermautotrophicus a stimulation of $\mathrm{CO}_{2}$ reduction to methane by methylcoenzyme M. It was suggested that the first and last steps of methanogenesis in these methanoarchaea are energetically coupled by a cytoplasmic enzyme complex that mediates flavin-based electron bifurcation (Thauer et al. 2008). The study of harmaline-resistant mutant opened the posibility to study the role of $\mathrm{Na}^{+} / \mathrm{H}^{+}$antiporter in these complex bioenergetic systems. Therefore we attempted to define on the protein level the molecular basis of the harmaline resistance and of accompanying phenotypic characteristics of the mutant strain. We compared the level of protein expression in different cellular fractions. The preliminary results of mass spectrometry analysis of membrane proteins in wild-type and harmaline-resistant cells revealed that the mutant strain contained significantly higher amounts of type A flavoprotein and molybdenum-containing formylmethanofuran dehydrogenase 1 subunit C. Low concentrations or absence of the $\mathrm{Na}^{+} / \mathrm{H}^{+}$antiporter in harmaline-resistant mutant might be compensated for by elevated amounts of type A flavoprotein and molybdenum-containing formylmethanofuran dehydrogenase participating in flavin-based electron bifurcation. All these findigs support the idea that $\mathrm{Na}^{+} / \mathrm{H}^{+}$exchanger might be a clue to the adaptative bioenergetic behaviour of $M$. thermautotrophicus under the different physiological conditions. Moreover this work provides the evidence that $\mathrm{Na}^{+} / \mathrm{H}^{+}$exchanger deficiency in harmalineresistant mutant can induce changes at the expression level of several genes participating in methanogenesis. The results imply that harmaline resistance is a consequence of decreased $\mathrm{Na}^{+} / \mathrm{H}^{+}$antiporter expression.

Acknowledgements. The authors gratefully acknowledge the technical assistance of Mrs. Petra Melicherová and Mrs. Lenka Országhová. This investigation was supported in part by the Slovak Research and Development Agency APVT-51- 024904, APVV-VVCE 0064-07 and by research grants VEGA 2/0015/09 from the Slovak Academy of Sciences and the Institutional Research Plan AV0Z40310501 of the Institute of Analytical Chemistry of the ASCR, v.v.i. M. V., J. B. and P. S. have no conflict of interest and no financial interest in the publication of this manuscript. 


\section{References}

Becher B., Müller V. (1994): $\Delta \tilde{\mu}_{\mathrm{Na}+}$ drives the synthesis of ATP via an $\Delta \tilde{\mu}_{\mathrm{Na}+}$-translocating $\mathrm{F}_{1} \mathrm{~F}_{0}$-ATP synthase in membrane vesicles of the archaeon Methanosarcina mazei Gö1. J. Bacteriol. 176, 2543-2550

Becher B., Müller V., Gottschalk G. (1992): The methyl-tetrahydromethanopterin:coenzyme M-methyltransferase of Methanosarcina strain Gö1 is a primary sodium pump. FEMS Microbiol. Lett. 91, 239-244

Deppenmeier U., Müller V., Gottschalk G. (1996): Pathways of energy conservation in methanogenic archaea. Arch. Microbiol. $165,149-163$ doi:10.1007/BF01692856

Deppenmeier U., Müller V. (2008): Life close to the thermodynamic limit: how methanogenic archaea conserve energy. Results and Probl. Cell Differ. 45, 123-152 doi:10.1007/400_2006_026

Gunsalus R. P., Wolfe R. S. (1977): Stimulation of CO2 reduction to methane by methyl-coenzynme $\mathrm{M}$ in extracts of Methanobacterium. Biochem. Biophys. Res. Commun. 76, 790-795 doi:10.1016/0006-291X(77)91570-4

Kaesler B., Schönheit P. (1989): The sodium cycle in methanogenesis. $\mathrm{CO} 2$ reduction to the formaldehyde level in methanogenic bacteria is driven by a primary electrochemical potential of $\mathrm{Na}+$ generated by formaldehyde reduction to $\mathrm{CH} 4$. Eur. J. Biochem. 186, 309-316 doi:10.1111/j.1432-1033.1989.tb15210.x

Laemmli U. K. (1970): Cleavage of structural proteins during the assembly of the head of bacteriophage T4. Nature 227, 680-685 doi: $10.1038 / 227680 \mathrm{a} 0$

Lowry O. H., Rosebrough N. J., Farr A. L., Randall R. J. (1951) Protein measurement with the Folin phenol reagent. J. Biol. Chem. 193, 265-275

Majerník A., Čuboňová L., Polák P., Šmigáň P., Greksák M. (2003): Biochemical analysis of neomycin-resistance in the methanoarchaeon Methanothermobacter thermautotrophicus and some implications for energetic processes in this strain. Anaerobe 9, 31-38 doi:10.1016/S1075-9964(03)00042-8

Ruppert C., Schmid R., Hedderich R., Müller V. (2001): Selective extraction of subunit $\mathrm{D}$ of the $\mathrm{Na}^{+}$-translocating methyltransferase and subunit $c$ of the $\mathrm{A}_{1} \mathrm{~A}_{0}$ ATPase from the cytoplasmic membrane of methanogenic archaea by chloroform/methanol and characterization of subunit $c$ of Methanothermobacter thermoautotrophicus as a $16-\mathrm{kD}$ a proteolipid. FEMS Microbiol. Lett. 195, 47-51 doi:10.1111/j.1574-6968.2001.tb10496.x

Schägger H., von Jagow G. (1987): Tricine-sodium dodecyl sulfatepolyacrylamide gel electrophoresis for the separation of proteins in the range from 1 to $100 \mathrm{kDa}$. Anal. Biochem. 166, 368-379 doi:10.1016/0003-2697(87)90587-2

Schäfer G., Engelhard M., Müller V. (1999). Bioenergetics of the Archaea. Microbiol. Mol. Biol. Rev. 63, 570-620

Schönheit P., Beimborn D. B. (1985): Presence of $\mathrm{Na}^{+} / \mathrm{H}^{+}$antiporter in Methanobecterium thermautotrophicum and its role in $\mathrm{Na}^{+}$ dependent methanogenesis. Arch. Microbiol. 142, 354-361 doi:10.1007/BF00491903

Schönheit P., Perski H. J. (1983): ATP synthesis driven by potassium diffusion potential in Methanobacterium thermoautotrophicum is stimulated by sodium. FEMS Microbiol. Lett. 20, 263-267 doi:10.1111/j.1574-6968.1983.tb00129.x

Šmigáň P., Friederová A., Rusnák P., Greksák M. (1984): Effect of 2,4-dinitrophenol and ionophores on growth and methanogenesis in Methanobacterium thermoautotrophicum. Folia Microbiol. 29, 353-358 doi:10.1007/BF02887762

Šmigán P., Majerník A., Polák P., Hapala I., Greksák M. (1995): The presence of $\mathrm{H}^{+}$and $\mathrm{Na}^{+}$-translocating ATPases in Methanobacterium thermoautotrophicum and their possible function under alkaline conditions. FEBS Lett. 371, 119-122 doi:10.1016/0014-5793(95)00866-8

Šurín S., Čuboňová L., Majerník A., McDermott P., Chong J. P. J., Šmigán P. (2007): Isolation and characterization of an amiloride-resistant mutant of Methanothermobacter thermautotrophicus possessing a defective $\mathrm{Na}^{+} / \mathrm{H}^{+}$antiport. FEMS Microbiol. Lett. 269, 301-308 doi:10.1111/j.1574-6968.2007.00655.x

Thauer K. R., Kaster A. K., Seedorf H., Buckel W., Hedderich R. (2008): Methanogenic archaea: ecologically relevant differences in energy consrvation. Nature Rev. Microbiol. 6, 579-591 doi:10.1038/nrmicro1931

Received: October 19, 2010

Final version accepted: November 28, 2010 